\title{
Epistemological and ethical understandings of access and allocation in Earth System Governance: a 10-year review of the literature
}

\author{
Agni Kalfagianni ${ }^{1}$ (D) Simon Meisch ${ }^{2}$
}

Accepted: 21 January 2020 / Published online: 28 January 2020

(c) The Author(s) 2020

\begin{abstract}
"Access and allocation" is one of the five analytical problems identified as key for analysing earth system governance in the first Earth System Governance Science and Implementation Plan officially published in 2009. Ten years later and with a new Science and Implementation Plan in place, it is time to take stock. Therefore, this paper addresses the question: What does a decadal review of the Earth System Governance literature tell us about how to conceptualize and define access and allocation, what ethical norms and epistemologies underlie access and allocation research, and what does Earth System Governance scholarship reveal about the interplay between access and allocation and other norms? We find that: (a) there is a relatively small body of the Earth System Governance literature on access and allocation, albeit growing; (b) this literature is largely empirical and dispersed across a variety of topics; and (c) there is a diversity of ethical norms and principles emphasized in Earth System Governance scholarship, but the dynamics between different forms of access and related implications for allocation are relatively underexplored. In light of these findings and with a new Earth System Governance Science and Implementation Plan in place, this paper highlights key areas for further research and development.
\end{abstract}

Keywords Access and allocation · Earth system governance $\cdot$ Harvesting $\cdot$ Justice

\author{
Abbreviations \\ CBD Convention on Biological Diversity \\ REDD Reducing emissions from deforestation and degradation \\ UNFCCC United Nations Framework Convention on Climate Change
}

Agni Kalfagianni

a.kalfagianni@uu.nl

Simon Meisch

simon.meisch@uni-tuebingen.de

1 Copernicus Institute of Sustainable Development, Utrecht University, Vening Meineszgebouw A, Princetonlaan 8A, 3585CB Utrecht, The Netherlands

2 International Center for Ethics in the Sciences and Humanities, University of Tübingen, Wilhemstr. 19, 72074 Tübingen, Germany 


\section{Introduction}

The Earth System Governance project introduced the analytical problem of access and allocation to address fundamental questions of "justice, fairness, and equity" in the first Earth System Governance Science and Implementation Plan officially published in 2009 (Biermann et al. 2009, p. 16). According to the project, justice is at the core of earth system governance (Biermann et al. 2010, p. 291). It concerns "any political activity, about the distribution of material and immaterial values" and "in essence, a conflict about the access to goods and about their allocation" (Biermann et al. 2009, p. 6).

The project defined access as "meeting the basic needs of humans to live a life of dignity" (Biermann et al. 2009, p. 60) or the "ability of individuals to secure a basic minimum of resources and ecospace" (Gupta and Lebel 2010, p. 379). Access has different interpretations in different studies. In the legal literature, for instance, access is associated with human rights, freedom of information and access to adjudication while in the economic literature, it is discussed in terms of human needs, employment and living wages (Biermann et al. 2009). A number of Earth System Governance scholars discuss access in relation to participation in decision-making procedures and opportunities for voice and contestation.

Allocation "goes beyond the issue of basic needs and looks at how the remainder of the resources can best be divided among people" (Gupta and Lebel 2010, p. 379). This understanding of allocation focuses on how land, water, minerals including oil, forests, species and ecosystems and their services are shared (Gupta and Lebel 2010). Beyond resources, allocation also refers to distribution of risks and burdens as well as rights and responsibilities (Biermann et al. 2009). In this context, allocation examines how problems are addressed from the perspective of the affected and those responsible, respectively (Gupta and Lebel 2010).

From the outset, the Earth System Governance project acknowledged that there was a great need for research on the understanding and implementation of justice, equity and fairness (see also Adger et al. 2005; and more recently: Forman and Mackie 2013; Klinsky et al. 2017). This paper presents the harvesting of 10 years of Earth System Governance research on access and allocation by using an epistemological and an ethical lens. The former lens examines how scholars affiliated with the Earth System Governance community as (senior) research fellows and lead faculty members dealt with normative statements related to access and allocation and, more precisely, if these statements were the objects or rather the aim of their research: Do they analyse how statements on justice, fairness or equity are represented and enacted in particular social or political contexts, i.e. make them an object of their research? Or do they argue for and substantiate a specific concept of justice, fairness or equity, i.e. make these statements the aim of their research? (O'Neill 2009). Meanwhile, the ethical lens reveals which ethical conceptions of access and allocation exist within the Earth System Governance text corpus and if and how they are substantiated. Obviously, the epistemological and ethical lenses are interrelated. The choice of a specific epistemological approach has ethical implications and vice versa (Anderson 2012; Potthast 2015; Meisch 2019). Analytically, however, it makes sense to distinguish the epistemological from the ethical lens, in order to provide specific insights for understanding the literature. We further examine the interplay between access and allocation and other norms, particularly effectiveness, knowledge, and power.

The review is based on the analysis of 62 articles over the period 2007-2017 (see Bibliography Annex). We identified these articles by examining the research output of those Earth System Governance fellows explicitly identifying access and allocation as a key area 
of their interest. The review aims at both reconstructing how the Earth System Governance scholarship conceptualized justice with regard to access and allocation, and revealing empirical insights generated by the research. In addition, on the basis of our analysis we are able to reflect on the contributions of the Earth System Governance literature to the broader field of equity and justice.

We first introduce epistemology and ethics as conceptual lenses in analysing access and allocation (1.). Subsequently, we use these lenses to analyse the empirical findings of the Earth System Governance literature on access and allocation, respectively (2.). We then review how this literature examined the interplay between access and allocation and other norms (3.) Finally, we conclude by highlighting a new research agenda for the next decade of Earth System Governance research (see also Earth System Governance 2018) (4.).

\section{Epistemology and ethics as lenses in analysing access and allocation}

The concept of justice relates to actions of people and the contexts they are acting in. Hence, all academic disciplines-such as political science, law, economics, geography, ethics, etc.-concerned with human coexistence address issues of justice. Yet, each discipline does so with regard to its own epistemological interest and methodological approaches (Gupta and Lebel 2010; Mazouz 2011).

We distinguish ethics from morals (or morality) (Meisch 2016, 2019). The academic literature uses both terms in different ways. It is important, though, that it becomes clear how they will be used subsequently. In line with the current moral-philosophical literature (Düwell 2013; Ricken 2013; Tugendhat 1993), we understand morals as the entirety of convictions held by individuals or communities about which aims are desirable ("the good life") or how they ought to act ("right actions"). So, morals relate to the evaluation of actions by asking how people can live truly successful lives or what they are obligated to do (Gewirth 1998; Nussbaum 2013; Sandel 2010). As attitudes, motives, intuitions, norms or institutions relate to actions in one way or another, they are subject to morals too. From morals (or morality), we distinguish ethics understood as the systematic reflection on the reasons why we ought to act in a particular way. Generally speaking, morals do not question their own justification; rather, they are simply lived. In contrast, ethics asks for reasons of validity. In daily life, people do this all the time. Academic ethics moves beyond this lifeworld reflection in a more systematic and methodical way (Gewirth 1998; Haker 2006, 2010).

Epistemologically, statements about what constitutes just/fair/equitable access and allocation are always "mixed moral judgments" or "thick descriptions" (Düwell 2013; Potthast 2015). These judgements consist of different descriptive and prescriptive elements about what is and what ought to be. As these mixed judgements encompass the knowledge and expertise of various disciplines, they are necessarily interdisciplinary. Statements about what constitutes just/fair/equitable access and allocation are thus to a certain degree normative because there are (more or less transparent) underlying assumptions about the good life and morally right actions (Düwell 2013; Klinsky and Dowlatabadi 2009). Related research can, for instance, focus on and analyse empirical aspects of moral judgements such as legal, political or economic contexts of access and allocation. Alternatively, political ethics and moral philosophy scholarship might try to unravel these underlying normativities, criticize them and substantiate claims of justice. So, many disciplines contribute to understanding issues of justice, equity and fairness. Yet, examining whether and in what 
sense these statements are morally justified lies within the competence of moral philosophy or ethics (Düwell 2013; O’Neill 2009).

\subsection{Epistemology}

The epistemological lens examines how researchers analytically explore statements on justice, i.e. whether they empirically identify representations of justice in particular social and political contexts or argue in favour of a particular conceptualization of justice (O'Neill 2009). Research taking justice as an object of research asks what tensions and inconsistencies exist regarding notions of justice. It analyses justice, equity and fairness of access and allocation from an empirical perspective. For instance, which understandings of justice, equity and fairness can be found in a specific political context? Which notions of justice are there with regard to a specific policy field? Or which institutions support which regimes of justice?

While this empirical research has an implicit understanding of what is just, fair and equitable, it would not argue for the validity of either particular claims of justice, the more general cases to which these claims apply, nor institutions that support the implementation of these claims (O’Neill 2009; Düwell 2013). These latter perspectives address justice as the aim of research aiming to substantiate normative statements about concepts and implementations of justice. As such, they fall within the scope of ethical research.

From an epistemological perspective, Gupta and Lebel (2010, p. 380) emphasize the interdisciplinary nature of justice questions related to access and allocation. Their overview demonstrates the diversity of approaches to this topic and points out that questions of just action and order require the knowledge and research methods of many disciplines. Accordingly, Gupta and Lebel (2010, pp. 390-391), rightly point out that any single disciplinary perspective on access and allocation would be too narrow to capture that diversity. Yet, for interdisciplinary cooperation the question arises as to the status of individual forms of knowledge and, with it, their relationship to normativity and normative claims (Düwell 2013; O'Neill 2009). Thus, the ethical basis of statements about justice becomes relevant. We turn to this next.

\subsection{Ethics}

The ethical lens explores existing claims for justice within law, policy or social practices in general and aim to argue for and substantiate (alternative) claims for justice. Traditionally, "[the] most plausible candidate for a core definition [of justice, the authors] comes from the Institutes of Justinian, a codification of Roman Law from the sixth century AD, where justice is defined as 'the constant and perpetual will to render to each his due"" (Miller 2017, emphasis in original). Obviously, when substantiating justice, we need to consider what it means to "render to each his due". This definition builds on the platonic philosophy (Tugendhat 1993, p. 367). Within the academic literature, there are some distinctions or conceptual pairs concerning justice that can help specify the concept (Table 1).

The first is the distinction between conservative and ideal justice (Miller 2017; Mazouz 2011). Conservative justice determines what is "due" by asking "what a person can reasonably expect to have, given the existing law, policy, or social practice", while through the ideal justice lens, justice is what a person should get under a regime of ideal justice: "this could mean what the person deserves, or needs, or is entitled to on grounds of equality, depending on which ideal principle is being invoked" (Miller 2017). Obviously, we would 


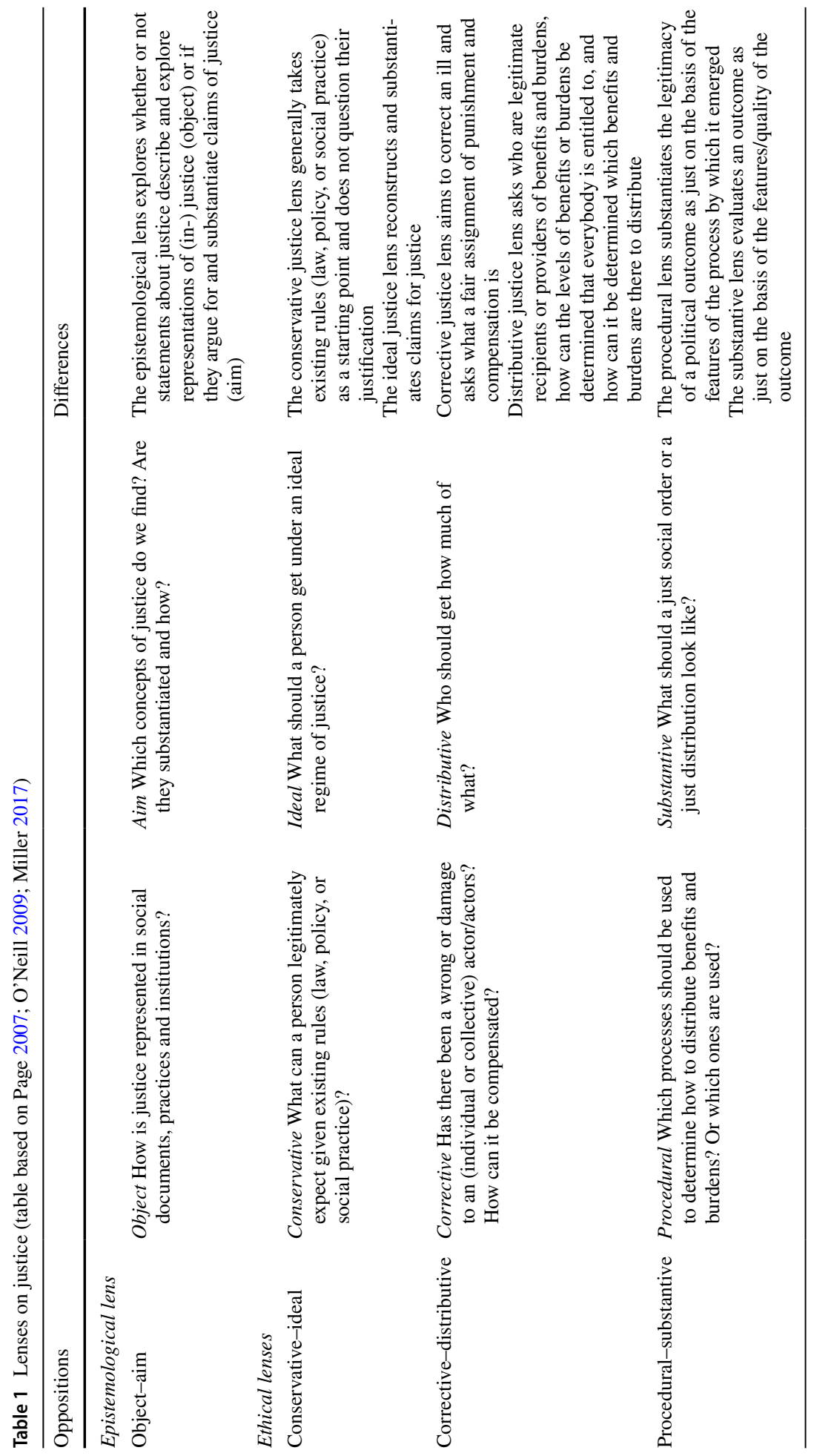


expect that notions of justice underlying the existing law, policy, or social practice refer to a regime of ideal justice. However, the discrepancy between law and morality has occupied Western political philosophy ever since Greek antiquity (Böhme 2001).

The second conceptual pair deals with the separation of corrective and distributive justice. This means distinguishing between justice "as a remedial principle that applies when one person wrongly interferes with another's legitimate holdings" (corrective) and "as a principle for assigning distributable goods of various kinds to individual people" (distributive) (Miller 2017). More precisely, distributive justice looks at who should get how much of what by asking who the legitimate recipients or providers of benefits and burdens are, how the levels of benefits or burdens can be determined so that everybody receives what they are entitled to, and how it can be determined which benefits and burdens are there to distribute (Page 2007). Tugendhat (1993, pp. 364-391) emphasizes that conceptions of distributive justice often focus primarily on the distribution of goods. Yet, in societies there is more to be distributed, namely rights, power, goods or compulsory enlistments (such as military services). Libertarian political philosophy disputes that goods are to be distributed at all (Kymlicka 2001, pp. 102-165; Tugendhat 1993, pp. 387-389). In any case, the literature on distributive justice raises awareness that the What? of distribution extends beyond goods only.

A third conceptual pair is between the justice of "the procedures that might be used to determine how benefits and burdens of various kinds are allocated to people" (procedural justice) and "the final allocation itself" (substantive justice) (Miller 2017). Again, both perspectives on justice overlap: Notions of procedural justice need substantive criteria to know what fair procedures are, while those approaches that look at final allocations can acknowledge that the process leading to this result ought to be fair too. So, the two perspectives are compatible. Yet, there are disciplinary traditions that refrain from establishing a substantive understanding of justice (Düwell 2013; O'Neill 2009).

These distinctions emphasize each a specific aspect of justice and have heuristic values. Quite often, they express a continuum rather than self-excluding alternatives and there is overlap between the pairs. For instance, corrective and distributive as well as procedural and substantive justice can be an issue of conservative and/or ideal justice. Or, notions of procedural and substantive justice have different approaches to distributive justice.

\section{Empirical observations on access and allocation through the lenses of epistemology and ethics}

We find that overall—while growing - there is a relatively small body of Earth System Governance literature on access and allocation and even less that has tried to explain the influence of access and allocation norms on global environmental governance (with exceptions, e.g. see: Okereke 2008). We did not find a clear thematic or geographical focus, although there is a slight tendency towards issues of climate change and ecosystem services and a focus on the local level. The review of this small body of the literature, nevertheless, revealed a rich diversity of perspectives on access and allocation.

\subsection{Access: epistemological and ethical analysis}

As mentioned earlier, researchers in the Earth System Governance project understand access as the "ability of individuals to secure a basic minimum of resources and ecospace" 
(Gupta and Lebel 2010, p. 379) or "meeting the basic needs of humans to live a life of dignity" (Biermann et al. 2009, p. 60). Looking through the epistemological lens, we would assume that the Earth System Governance literature would confront the ethical task of arguing for and substantiating what living a life of dignity means, what this implies for determining a basic minimum of resources and eco-space or basic needs and finally how they can be operationalized in particular social contexts (e.g. Klinsky and Dowlatabadi 2009; Martin et al. 2016; Meisch 2016; Okereke and Dooley 2010). In equal manner, we would expect literature which empirically studies how "basic needs" or "living a life of dignity" are represented in political and social contexts and which assess if and to what degree these contexts promote or impede access (e.g. Corbera et al. 2007; Corbera and Schroeder 2011; Bastos Lima and Gupta 2013). We find both lenses within the Earth System Governance literature. Klinsky and Dowlatabadi (2009) and Klinsky et al. (2017, pp. 171-172), in particular, highlight the importance of both, and call for a proactive debate on justice issues in climate change policy research. They speak of an "obligation to address human wellbeing" (Klinsky et al. 2017, p. 171) for "[r]igorous analysis that systematically considers the issue of justice is essential for our ability to understand and meaningfully inform the politics of climate action, especially in the post-Paris world" (Klinsky et al. 2017 , p. 172). Below, we present our findings in more detail.

First, we find papers that discuss justice with regard to political or legal documents such as the Ramsar Convention, the Convention on Biological Diversity or REDD+. These studies are mainly concerned with the just, fair or equitable implementation of these agreements and less so with using them as the reference points for substantiating justice, equity or fairness. Therefore, we do not classify them as examples of conservative justice. In contrast, we find a discernible engagement with ideal justice. Related papers identify philosophical approaches and compare their particular contribution to determining access, i.e. securing a basic minimum of resources and eco-space or meeting the basic needs of humans to live a life of dignity.

In their study on avoided deforestation, Okereke and Dooley (2010, p. 82) emphasize "the growing realization that the international arena is not beyond the pale of moral arguments but rather that the governance of global environmental change implicates elemental ethical questions regarding which ways of life human beings ought to pursue". The authors draw attention to a pluralism of theories of justice which can be found in the academic literature (utilitarianism; liberal egalitarianism; market justice; justice as mutual advantage; communitarianism; meeting needs) and show for their case which normative implications and political effects each of these theories have. They suggest that further (meta-) analytical research is needed to assess whether some approaches are preferable to others and if so why.

Martin et al. (2016) criticize the dominant, Western ways to determine conservation justice that ignore "other cultures and other ways of thinking about justice in relation to the environment" which, in turn, affects access to political and knowledge-production processes. The authors focus on "recognition" in conservation justice, i.e. "respecting identities and cultural difference", in particular of indigenous people in nature conservation policies (Martin et al. 2016, pp. 255-259). As they believe that "a single definition of justice-as-recognition [...] would ignore important differences in understanding, including among political philosophers" (Martin et al. 2016, p. 255), they compare and discuss four understandings of recognition (Hegelianism, Critical theory, De-colonialism, Capabilities).

Building on the theories of justice by Martha Nussbaum and Alan Gewirth, respectively, Meisch (2016, pp. 67-68) develops what it means to live a life of dignity, and what this implies for determining access. Nussbaum's Capability Approach and Gewirth's Principle 
of Generic Consistency each identify entitlements of every human to live a life of dignity. Both argue for the normative claim that human dignity possesses an overriding priority over other practical considerations. To them, dignity signifies what humans owe each other and what can legitimately claim to be included in political and legal rules. They specify the aspects of human life that are indispensable parts of human dignity, create direct obligations to other humans and the state and are thus the basis for determining access.

Second, with regard to the corrective-distributive conceptual justice pair, we find a discernible interest in the questions of what people need access to and what thus needs to be distributed (distributive justice). In their conceptual paper, Gupta and Lebel (2010, pp. 380-382) draw attention to the fact that this question cannot relate solely to resources but must also extend to the possibility of participation in processes of political decisionmaking. Corbera et al. (2007) address different aspects of justice in relation to access to ecosystem services. They ask about the fair distribution of access rights to markets, networks and processes of knowledge production. In doing so, they highlight the weaknesses of certain political solutions, especially the market approach in particular leading to unjust global distributions affecting local communities. They propose a three-tiered equity framework covering procedural, substantial and distributive aspects: "equity in access, equity in decision-making and equity in outcome. Equity in access concerns the way in which individual farmers, rural communities and organisations are able to participate in emerging markets. This depends on access to information, knowledge and networks, as well as on access to land and forest resources" (Corbera et al. 2007, p. 368). With regard to the corrective-distributive lenses, we also found many articles studying the close relationship of corrective and distributive justice. Corbera and Schroeder (2011) in particular combine both justice lenses. The authors deal not only with how rights of access to information and participation can be fairly distributed, but also with "the un-doing of perceived injustices" (Corbera and Schroeder 2011, p. 94). Other authors examine how aspects of corrective and distributive justice can be imagined together. This perspective results from their research interests in environmental governance in Africa and climate policy. In both cases, they are addressing future-oriented policies, each of which has its own specific (colonial) background (Habtezion et al. 2015; Kanie et al. 2010).

Third, we find a greater focus on issues of procedural than on substantive justice and in particular the question of how local communities can have access to ecosystem services when previous approaches of resource governance have failed and responses to emerging sustainability challenges are needed. Salisu Barau and Stringer (2015, p. 170) raise the questions of how international sustainability conventions (such as the Ramsar Convention and Convention on Biological Diversity, CBD) can be implemented in such a way that no new injustices arise locally and what (whose) knowledge is included in the description of the local problem to be solved. They thus refer to an important aspect of procedural justice, namely the right of people to contribute to the definition of the problem that concerns them themselves and that is to be solved politically. This reveals the close connection between aspects of knowledge and power. Corbera and Schroeder (2011) are also concerned with access to ecosystems and the governance and implementation of international agreements, in their case REDD+. They emphasize procedural aspects of justice, ranging from access to information of indigenous peoples and local communities to access to participation in all stages of the establishment and management of REDD+ sites. Coolsaet and Pitseys (2015) present an approach to procedural justice that is critical of substantial understandings of justice. They clearly spell out what they mean by procedural justice, i.e. that everyone can participate in decision-making processes and influence them to a sufficient degree. Their research "contributes to previous research pointing to the use of normative argumentation 
in multilateral environmental negotiations as a strategy to alter the ways parties define, frame, and understand what is and what ought to be" (Coolsaet and Pitseys 2015, p. 51).

Fourth, in their study on the policy contexts of biofuels, Bastos Lima and Gupta (2013) indicate one way in which access and allocation interrelate. The authors emphasize that access must not be limited to goods alone, but should also include rights and the possibility to participate in political processes. Their paper focuses on the global level and the possibility for non-state actors of the global South to participate in political processes. Bastos Lima and Gupta show how allocation issues in the global North produce access problems in the global South. Overall, however, there is no systematic research on the conceptual and empirical relationship between access and allocation (cf. e.g. Spengler 2016).

In summary, the access literature of Earth System Governance research explores justice from different perspectives. Epistemologically, we find some papers making statements on justice as the aim of their study, in particular those using an ideal justice lens. With regard to ethical lenses, there is an emphasis on distributive and procedural justice.

\subsection{Allocation: epistemological and ethical analysis}

Epistemologically, questions of allocation tend to the object rather than the aim of research in the Earth System Governance literature. Indeed, efforts focus on identifying which notions - mostly of distributive justice-are represented in policy documents, practices and institutions rather than in arguing in favour of particular ideal conceptualizations of justice. This is related, most likely, to the predominantly social scientific background of the Earth System Governance community working on these issues and the relatively little (up to now) involvement from philosophy and legal disciplines. Related to this epistemological focus, the ethical analysis also reveals that the majority of the allocation literature examined here explores - and often also contests - existing claims for justice. It nonetheless focuses less on arguing for and substantiating (alternative and/or new) claims for justice.

More specifically, first, we find that the allocation literature is often concerned with conservative justice in that it takes the existing rules and global governance institutions as a given but with a view to clarifying their underlying ethical principles and critically reflecting on their inadequacies. Although it does not contemplate ideal claims for justice, it relies on existing ideal and non-ideal approaches to justice in order to evaluate current policies, predominately in the climate domain. For example, examining which notions of distributive justice permeate environmental policy and governance, Klinsky and Dowlatabadi (2009, pp. 89-94) use an applied ethics approach to examine which distribution rules are applied in climate policy, how the problem of climate change and climate policy is understood and which metrics are used to measure costs and benefits. They find that visions of distributive justice within climate policy are narrow which in turn may limit our understanding of which options are available and present the best fit with the climate change challenge. Likewise, Okereke and Dooley (2010, pp. 84-86) draw on theories of distributive justice to determine which interpretations of equity are embodied in the key proposals and policy approaches to REDD in the run up to the post-Kyoto climate agreement and indicate the potential practical consequences of such approaches. They use six broad principles of justice as the basis of a framework from which to analyse the different REDD proposals: utilitarianism; liberal egalitarianism; market justice; justice as mutual advantage; communitarianism; meeting needs. They find that nearly all proposals before the UNFCCC include varying and sometimes conflicting notions of justice. But they prioritize those proposals that are consistent with market-based conceptions of justice. 
Second, we also find that the literature on allocation focuses in particular on questions of distributive justice. Within this part of the literature, we can broadly identify (a) efforts to elaborate upon and operationalize distributive justice into criteria and indicators and (b) distributive justice impacts from current policies and solutions to environmental challenges. To illustrate the development of distributive justice criteria and indicators, Stadelmann et al. (2014) investigate indicators necessary to allocate international funding for adaptation to climate change given the challenge of prioritizing project proposals subject to limited funding. They associate distributive justice with equity which they define based on Adams (1965) as distribution of resources perceived as fair by relational partners. Reviewing political science literature on equity in the context of vulnerability-which they perceive as the most important condition in relation to adaptation finance-they develop three equity indicators: equal funding per capita (proxy for equality between individuals); support for the most vulnerable countries; and support for the poorest countries as measured by their Gross Domestic Product per capita. Applying these criteria to 39 Adaptation Fund (AF) projects, they find that contrary to AF's goal, it has rather approved projects from high-income and less vulnerable countries with high absolute economic savings while not approving projects in poor, vulnerable countries with high relative economic savings.

Kanie et al. (2010), on the other hand, try to quantify allocation criteria under the "common but differentiated responsibility" principles of the United Nations Framework Convention on Climate Change (UNFCCC). They note that the debate on climate policy at the time of writing their article was on the reallocation of economic benefits. They examine three allocation criteria: responsibility (the extent to which each country is responsible for climate change); capability (or ability to pay); and efficiency (of actions to reduce greenhouse gas emissions). They point out the difficulties in translating these criteria into quantifiable calculations and that scenarios based on quantifiable criteria are not value free and often value biases are not understood beyond the narrow circles of experts. In this context, they underline the importance of interdisciplinary collaborations in order to avoid contradictions and unravel the ethical biases.

Regarding impacts, the Earth System Governance literature points out that the poor and marginalized are the principle affected parties of global environmental governance. Thus, in their analysis of biofuel governance Bastos Lima and Gupta (2013, p. 58) note that "biofuel research, development and production have mostly been linked to consolidated agricultural sectors rather than to small-scale agriculture or to strategies that target poverty". The growing volume of produced biofuels goes to higher-income consumers. Much biofuel production is allocated to the South to meet Northern demands. According to the authors, this can aggravate existing equity needs. Corbera and Schroeder (2011, pp. 94-95) in their introduction to the special issue on governance and implementation of REDD+ from an allocation perspective ask whether the distribution mechanisms of REDD+ would reach all those who have contributed to preserving forests; how forests and indigenous communities who may not enjoy tenure rights can trust that they will be compensated for their efforts under REDD+; and what the social and environmental safeguards under REDD+ are. Citing other research they point out that there is an uneven distribution of activities across tropical countries. Specifically, the largest share of REDD readiness and demonstration activities was implemented in Indonesia and Brazil which is related to these countries' greatest forest emission reduction potential. Based on these and other country related characteristics, they point out a strong bias towards African countries (Cerbu et al. 2011).

However, corrective justice is also examined albeit less often. Here, different propositions can be identified. Gupta and Lebel (2010) propose a multidisciplinary perspective on the study of access and allocation and illustrate its application to water management 
and climate change. Regarding allocation in particular they note the absence of any clear mechanisms for allocating responsibilities for dealing with environmental risks. They give the example of the polluter pays principle that has turned into the polluter gets paid principle under emissions trading systems for climate change mitigation. (Instead of being held accountable, polluters are allowed to trade their emissions). They note dependence of allocation (and access) on the role of social actors, coalitions and movements in debating, promoting and pushing for access and allocation, mobilizing resources, science and technology and actually ensuring the implementation of access and allocation. They also adopt a language of rights as allocation issues are often mired in historical systems of rights.

Taking a different approach, Zeitoun et al. (2016, p. 149) attribute the causes of inequitable distributions of benefits and risks to a political economy that disadvantages those who are already vulnerable or marginalized. Accordingly, they propose the "confrontation of the political, economic and technological arrangements that some judge as unfair or unsustainable, even where more powerful actors might argue these are reasonable". In this context, Gupta (2018, p. 267) argues in favour of examining climate finance particularly for adaptation purposes which in its current form appears to "shift the risk of burden from those who gain from fossil fuel use, to those who are affected".

Habtezion et al. (2015) in one of the few studies with a focus on Africa note the importance of benefit sharing for communities whose livelihoods are most affected by climatic stresses. They put particular emphasis on finance and propose that priority research should ask: what policy and regulatory tools are helpful in ensuring effective and equitable handling or management of resources. They further advise that such research needs to examine how to minimize corruption; how to promote equitable sharing of benefits and burdens of global environmental change in Africa; and how to frame the developed countries obligations to mitigate adverse effects that accrue to Africa and what can Africa do on its part. Finally, the authors ask for clarity and tools to identify opportunities for finance and identify the best way to define the rules of access to human and financial resources and accompanying capacity and economic limitations facing Africa.

Third, the allocation literature examined here also tries to link questions of allocation with procedural requirements. Regarding procedural requirements, this literature points to the importance of procedures for the fairness of distribution. Thus, Coolsaet and Pitseys (2015) in their review of the notion of fair and equitable sharing as understood in the Nagoya Protocol note the importance of examining the material, social, cultural and institutional circumstances within which the decision-making structure that leads to the distribution of benefits and burdens takes place. Fairness and equity of a benefit sharing agreement thus depend on a decision-making procedure governed by principles of procedural justice. In this context, the authors demonstrate the importance of using normative argumentation driven by arguments of public interest as a strategy to alter the way parties define, frame and understand what is and what ought to be served to the benefit of the disadvantaged; and the importance of formal equality in target and process-based negotiation strategies (one country-one vote). Martin et al. (2016) discuss distribution alongside the procedural and recognition dimensions in a tripartite framework. They define distribution as "differences between stakeholders in terms of who enjoys rights to material benefits and who bears costs and responsibilities". While the paper's emphasis is on recognition, this is often considered the basis for meaningful participation (Fraser et al. 2004).

Finally, a few scholars try to make the link between allocation and substantive sustainability outcomes. Thus, in an editorial Schroeder (2014) explores the existence of links between inequitable access and allocation and severe ecological degradation and social stress in the nitrogen cycle, biodiversity and climate change. She concludes that ultimately 
these issues are a feature of inadequate governance. Andersson and Agrawal (2011) examine how equality and ecological sustainability are related by drawing upon data from multiple localities in several countries in the developing world (India, Nepal. Kenya, Uganda, Bolivia and Mexico). They show that economic inequalities, in particular, have consistently negative effects on resources. But these can be moderated by local institutional arrangements as measured by the strength of collective action for different joint activities among users. Specifically, when local forest users are well organized and have effective rule-making, monitoring and enforcement systems in place, they are found to systematically reduce the detrimental effects that inequality between groups have on forest conditions.

In short, the allocation literature of Earth System Governance research uses different ethical lenses to examine allocation questions, with an emphasis on distributive justice and a reliance on applied rather than ideal norms of justice.

\section{Interplay between access and allocation and other norms}

We now examine the interplay between access and allocation and other norms that the Earth System Governance project has emphasized as crucial for providing an integrated understanding of earth system governance (Biermann et al. 2009; Kuyper et al. 2017). These norms are effectiveness, knowledge and power.

A number of scholars underline the interplay between access and allocation, on the one hand, and effectiveness, on the other in either a positive or negative way. Some scholars associate the emphasis on economic efficiency and cost-effectiveness in distributive justice proposals as the primary concern of neoliberal environmental policy (Okereke 2008). Okereke and Dooley (2010, p. 91) note, in particular that one of the clearest manifestations of the dominance of neoliberalism in global environmental decision-making arenas is that the idea of equity is strongly tied to the concepts of performance and efficiency both of which are at the heart of market-based approaches to justice.

Others argue that there is not necessarily a contradiction between access and allocation and effectiveness. Meisch (2016, p. 74) points out that effective governance approaches must obviously not contradict fair distribution. The balance between justice and effectiveness is likely to become complicated, especially with regard to scarce resources. Different moral considerations can play a role in this balancing. However, it is quite hard to argue for an effective but unfair political solution. In addition, in the context of climate change, for instance, Klinsky et al. (2017, p. 172) argue that "equity" is not always in tension with effective collective climate action particularly from the perspective of those who stand to lose. Schroeder (2014) going a step further finds that poorly designed governance is in fact very much related to exclusion, social and economic inequality and usurpation of allocative rights.

Still others point out that the definition of effectiveness matters in this case. Thus, in their examination of potential trade-offs between equity and cost-effectiveness Stadelmann et al. (2014) find that a pure economic definition of cost-effectiveness is in contradiction with equity. But trade-offs can be limited if relative economic savings (the percentage of annual income saved, multiplied with the number of beneficiaries) or human live savings (measured in Disability Adjusted Life Years Saved, an indicator used by the World Health Organization) are used as indicators of cost-effectiveness.

Several scholars of the Earth System Governance community discuss issues of access and allocation in relation to knowledge produced and diffused by societal actors. They 
point out that knowledge generated by social movements and environmental justice organizations, in particular, increased in parallel to the pressures they experienced (MartinezAlier et al. 2014; Anguelovski and Martínez Alier 2014). And this helped to spread the environmental justice frame-geographically in space, horizontally across a broad range of issues, vertically in the global nature of injustices, and conceptually in relationships with the non-human world-hence integrating and empowering widely different movements and concerns (Schlosberg 2013). As a result, contemporary environmental justice discourses provide a common frame for those who confront different forms of domination in which environmental conditions in particular are at stake (Agyeman 2014; Sikor and Newell 2014).

A smaller number of scholars also examine the interplay between access and allocation and knowledge from a more pluralistic perspective. They point out, for example, the marginalisation of indigenous and local knowledge in understanding and addressing the governance challenges of global environmental change. Such knowledge, these scholars argue, is vital, however, in bringing a more holistic worldview of nature and of human-nature relationships in contrast to the dichotomies (human versus nature) produced by modernity (Inoue and Moreira 2016; Inoue and Tickner 2016; Parsons et al. 2017). This is because many indigenous cultures place a higher value on the spiritual and non-material aspects of all living species than what is often represented by Western discourses and governance approaches (see also Kohler et al. 2019).

Next to knowledge, power is related to access and allocation through struggles to overcome injustice and through influence over whose justice perspective is being advanced. Gupta and Lebel (2010) point out that allocation and access are always intertwined with power struggles, but these differ across issue areas. In the context of their research, they argue that power struggles on water are essentially local and regional in nature while power struggles on climate are global in nature and with higher political stakes involved. Likewise, Zeitoun et al. (2016) discussing the politics of water security argue that water security policy and projects aimed at the most vulnerable should take into account power asymmetries. In this context, they note that the group that benefits the most might often be the very group that defines what level of risk is tolerable for other groups. However, few Earth System Governance scholars engage with the idea that the framing of environmental justice is itself a political issue, in other words that the "the construction of an environmental justice frame is itself a political process that requires confronting and negotiating multiple dimensions of identities" (Avc1 2017, p. 8).

\section{Conclusion and future outlook}

The aim of this review was to reconstruct Earth System Governance's conceptualizations of justice with regard to access and allocation over the past decade, to put them in relation to each other, and to make the existing research visible, so that future work can build on this foundation of what has been achieved so far.

Our results indicate that the Earth System Governance literature on access and allocation over the past 10 years is small but significant. Specifically, it provides a rich diversity of perspectives and knowledge in particular from distributive and procedural justice perspectives even though less on substantive justice questions. It further provides rich empirical material from a plurality of fields even though the emphasis lies primarily on the local level with a tendency towards issues of climate change and ecosystem 
services. Accordingly, this literature makes a substantial contribution to the larger field of equity and justice by conceptualizing and empirically investigating access and allocation in the context of profound transformations of the earth system.

Despite the achievements of Earth System Governance research on access and allocation, some blind spots remain. There is, for example, little attention to the relation between access and allocation, such as how different forms of access may affect allocation and vice versa. Further, while there is a range of Earth System Governance scholarship analysing the relationship between access and allocation and other norms, specifically effectiveness, knowledge and power, no clear patterns and interpretations of such relationships for earth system governance can be identified.

Future research, then, needs to further examine the dynamics between different conceptualizations of justice as well as between justice and questions of effective governance, different ways of knowing and political empowerment (cf. e.g. Klinsky et al. 2017; Schroeder and McDermott 2014). In this context, Earth System Governance scholars can engage more explicitly with literature addressing everyday practices and materiality (e.g. Alkon and Agyeman 2011; Gabrielson and Parady 2010; Schlosberg and Coles 2015), place, culture and identity (Agyeman 2013; Escobar 2001), as well as the relationship between human and non-human nature (Mohai et al. 2009). In addition, examining justice questions in the context of planetary boundaries and the Anthropocene, as well as with more concrete-related plans of action such as the Sustainable Development Goals and the emergence of science-based Earth target-setting initiatives (such as the Earth Commission), are promising new research domains. Further, looking beyond Western political philosophy and thereby engaging with alternative visions of justice, such as "buen vivir" (see Vanhulst and Beling 2014) and Ubuntu (see LenkaBula 2008) is extremely pertinent.

Here, we would also like to highlight the relevance of the new research agenda of the Earth System Governance project for developing future research questions on justicerelated research. The new science and implementation plan argues that "questions of justice and allocation are becoming central political discourses in a world with growing inequalities within and across national borders" (Earth System Governance 2018, p. 56). Building on the knowledge gained over the past decade via the Earth System Governance community and beyond, the plan proposes an explicit justice lens which would need to clarify the subjects, principles, mechanisms and instruments for justice. It argues that justice-related research in the realms of Earth System Governance needs to take into account justice between generations, states and regions, groups in society and between species as subjects of justice (for the latter see Kalfagianni et al. 2019). It needs to integrate different perspectives on justice particularly those related to distribution, representation and recognition as repeatedly noted by justice philosophers (Düwell et al. 2018; Fraser et al. 2004; Robeyns 2019; Anderson 2012) and environmental justice scholars (Schlosberg 2013). And it needs to clearly identify which legal, economic and procedural governance mechanisms are responsible for creating injustice and which can be used to foster greater justice (O’Neill 2009).

For this, we echo scholars who call for more interdisciplinary approaches to better understand the outcomes associated with mechanisms to advance justice and how best to understand success in achieving it. The integration of theoretical constructs and methodologies from diverse disciplines can allow us to better understand the most fruitful governance pathways for addressing injustices in distribution, recognition or representation of the various subjects of justice. Related to that, we call for a continuous synthesis of knowledge (that has so far developed in rather disparate and mostly empirical ways) that can enhance 
collective learning and further develop our conceptual understanding of justice in global environmental governance.

Open Access This article is licensed under a Creative Commons Attribution 4.0 International License, which permits use, sharing, adaptation, distribution and reproduction in any medium or format, as long as you give appropriate credit to the original author(s) and the source, provide a link to the Creative Commons licence, and indicate if changes were made. The images or other third party material in this article are included in the article's Creative Commons licence, unless indicated otherwise in a credit line to the material. If material is not included in the article's Creative Commons licence and your intended use is not permitted by statutory regulation or exceeds the permitted use, you will need to obtain permission directly from the copyright holder. To view a copy of this licence, visit http://creativecommons.org/licenses/by/4.0/.

\section{References}

Adams, J. S. (1965). Inequity in social exchange. In L. Berkowitz (Ed.), Advances in experimental social psychology (Vol. 2, pp. 267-299). Cambridge: Academic Press.

Adger, W. N., Brown, K., \& Hulme, M. (2005). Redefining global environmental change (editorial). Global Environmental Change: Human and Policy Dimensions, 15(1), 1-4.

Agyeman, J. (2013). Introducing just sustainabilities: Policy, planning and practice. London: Zed Books.

Agyeman, J. (2014). Environmental justice and sustainability. In G. Atkinson, S. Dietz, \& E. Neumayer (Eds.), Handbook of sustainable development (pp. 171-188). London: Edward Elgar.

Alkon, A. H., \& Agyeman, J. (Eds.). (2011). Cultivating food justice: Race, class, and sustainability. Cambridge, MA: MIT Press.

Anderson, E. (2012). Epistemic justice as a virtue of social institutions. Social Epistemology, 26(2), 163173. https://doi.org/10.1080/02691728.2011.652211.

Andersson, K., \& Agrawal, A. (2011). Inequalities, institutions, and forest commons. Global Environmental Change, 21(3), 866-875. https://doi.org/10.1016/j.gloenvcha.2011.03.004.

Anguelovski, I., \& Martínez Alier, J. (2014). The 'Environmentalism of the Poor' revisited: Territory and place in disconnected glocal struggles. Ecological Economics, 102, 167-176. https://doi.org/10.1016/j. ecolecon.2014.04.005.

Avc1, D. (2017). Mining conflicts and transformative politics: A comparison of Intag (Ecuador) and Mount Ida (Turkey) environmental struggles. Geoforum, 84, 316-325. https://doi.org/10.1016/j.geofo rum.2015.07.013.

Bastos Lima, M. G., \& Gupta, J. (2013). The policy context of biofuels: A case of non-governance at the global level? Global Environmental Politics, 13(2), 46-64. https://doi.org/10.1162/GLEP_a_00166.

Biermann, F., Betsill, M. M., Gupta, J., Kanie, N., Lebel, L., Liverman, D., et al. (2009). Earth System Governance: People, places and the planet. Science and implementation plan of the Earth System Governance Project. Bonn: The Earth System Governance Project.

Biermann, F., Betsill, M. M., Gupta, J., Kanie, N., Lebel, L., Liverman, D., et al. (2010). Earth system governance: A research framework. International Environmental Agreements: Politics, Law and Economics, 10(4), 277-298. https://doi.org/10.1007/s10784-010-9137-3.

Böhme, G. (2001). Ethics in context: The art of dealing with serious questions. Cambridge: Polity.

Cerbu, G. A., Swallow, B. M., \& Thompson, D. Y. (2011). Locating REDD: A global survey and analysis of REDD readiness and demonstration activities. Environmental Science \& Policy, 14(2), 168-180. https ://doi.org/10.1016/j.envsci.2010.09.007.

Coolsaet, B., \& Pitseys, J. (2015). Fair and equitable negotiations? African influence and the international access and benefit-sharing regime. Global Environmental Politics, 15(2), 38-56. https://doi. org/10.1162/GLEP_a_00297.

Corbera, E., Kosoy, N., \& Martínez Tuna, M. (2007). Equity implications of marketing ecosystem services in protected areas and rural communities: Case studies from Meso-America. Global Environmental Change, 17(3), 365-380. https://doi.org/10.1016/j.gloenvcha.2006.12.005.

Corbera, E., \& Schroeder, H. (2011). Governing and implementing REDD+. Environmental Science \& Policy, 14(2), 89-99. https://doi.org/10.1016/j.envsci.2010.11.002.

Düwell, M. (2013). Bioethics: Methods, theories, domains. London: Routledge.

Düwell, M., Bos, G., \& van Steenbergen, N. (Eds.). (2018). Towards the ethics of a green future. London: Routledge. 
Earth System Governance. (2018). Science and implementation plan of the Earth System Governance Project. Utrecht: Earth System Governance.

Escobar, A. (2001). Culture sits in places: Reflections on globalism and subaltern strategies of localisation. Political Geography, 20, 139-174.

Forman, F., \& Mackie, G. (2013). Introduction: New frontiers in global justice. Critical Review of International Social and Political Philosophy, 16(2), 151-161.

Fraser, N., Hanne Marlene, D., Pauline, S., \& Rasmus, W. (2004). Recognition, redistribution and representation in Capitalist Global Society: An interview with Nancy Fraser. Acta Sociologica, 47(4), 374-382.

Gabrielson, T., \& Parady, K. (2010). Corporeal citizenship: Rethinking green citizenship through the body. Environmental Politics, 19, 374-391.

Gewirth, A. (1998). Self-fulfillment. Princeton: Princeton University Press.

Gupta, J. (2018). Sharing our water. In J. Vos, R. Boelens, \& T. Perreault (Eds.), Water justice (pp. 259274). Cambridge: Cambridge University Press.

Gupta, J., \& Lebel, L. (2010). Access and allocation in earth system governance: Water and climate change compared. International Environmental Agreements: Politics, Law and Economics, 10(4), 377-395. https://doi.org/10.1007/s10784-010-9139-1.

Habtezion, S., Adelekan, I., Aiyede, E., Biermann, F., Fubara, M., Gordon, C., et al. (2015). Earth System Governance in Africa: Knowledge and capacity needs. Current Opinion in Environmental Sustainability, 14, 198-205. https://doi.org/10.1016/j.cosust.2015.06.009.

Haker, H. (2006). Narrative bioethics. In C. Rehmann-Sutter, M. Düwell, \& D. Mieth (Eds.), Bioethics in cultural contexts: Reflections on methods and finitude (pp. 353-376). Springer: Kluwer.

Haker, H. (2010). Narrative Ethik. Zeitschrift für Didaktik der Philosophie und Ethik, 2, 74-83.

Kalfagianni, A., Gerlak, A., Olsson, L., \& Scobie, M. (2019). Justice. In A. Kalfagianni, D. Fuchs, \& A. Hayden (Eds.), Handbook of global sustainability governance. London: Routledge.

Kanie, N., Nishimoto, H., Hijioka, Y., \& Kameyama, Y. (2010). Allocation and architecture in climate governance beyond Kyoto: Lessons from interdisciplinary research on target setting. International Environmental Agreements: Politics, Law and Economics, 10(4), 299-315. https://doi.org/10.1007/s1078 4-010-9143-5.

Klinsky, S., \& Dowlatabadi, H. (2009). Conceptualizations of justice in climate policy. Climate Policy, 9(1), 88-108. https://doi.org/10.3763/cpol.2008.0583b.

Klinsky, S., Roberts, T., Huq, S., Okereke, C., Newell, P., Dauvergne, P., et al. (2017). Why equity is fundamental in climate change policy research. Global Environmental Change, 44, 170-173. https://doi. org/10.1016/j.gloenvcha.2016.08.002.

Kuyper, J. W., Linnér, B., \& Schroeder, H. (2017). Non-state actors in hybrid global climate governance: Justice, legitimacy, and effectiveness in a post-Paris era. WIREs Climate Change, 9(1), e497. https:// doi.org/10.1002/wcc.497.

Kymlicka, W. (2001). Contemporary political philosophy: An introduction. Oxford: Oxford University Press.

Martin, A., Coolsaet, B., Corbera, E., Dawson, N. M., Fraser, J. A., Lehmann, I., et al. (2016). Justice and conservation: The need to incorporate recognition. Biological Conservation, 197, 254-261. https://doi. org/10.1016/j.biocon.2016.03.021.

Martinez-Alier, J., Anguelovski, I., Bond, P., Del Bene, D., Demaria, F., Gerber, J.-F., et al. (2014). Between activism and science: Grassroots concepts for sustainability coined by Environmental Justice Organizations. Journal of Political Ecology, 21(1), 19-60.

Mazouz, N. (2011). Gerechtigkeit. In M. Düwell, C. Hübenthal, \& M. Werner (Eds.), Handbuch Ethik (pp. 365-371). Stuttgart: Metzler.

Meisch, S. (2016). A fair distribution in the Anthropocene: A normative conception of sustainable development. In P. Pattberg \& F. Zelli (Eds.), Environmental politics and governance in the Anthropocene. Institutions and legitimacy in a complex world (pp. 62-78). London: Routledge.

Meisch, S. (2019). I want to tell you a story: How narrative water ethics contributes to re-theorizing water politics. Water. https://doi.org/10.3390/w11040631.

Miller, D. (2017). Justice. In E. N. Zalta (Ed.), The Stanford Encyclopedia of Philosophy (Fall 2017 Edition).

Mohai, P., Pellow, D. V., \& Roberts, J. T. (2009). Environmental justice. Annual Review Environmental Resources, 34, 405-430.

Nussbaum, M. (2013). Creating capabilities: The human development approach. Cambridge, MA: Belknap Press.

O’Neill, O. (2009). Applied ethics: Naturalism, normativity and public policy. Journal of Applied Philosophy, 26(3), 219-230. https://doi.org/10.1111/j.1468-5930.2009.00446.x. 
Okereke, C. (2008). Equity norms in global environmental governance. Global Environmental Politics, 8(3), 25-50. https://doi.org/10.1162/glep.2008.8.3.25.

Okereke, C., \& Dooley, K. (2010). Principles of justice in proposals and policy approaches to avoided deforestation: Towards a post-Kyoto climate agreement. Global Environmental Change, 20(1), 82-95. https ://doi.org/10.1016/j.gloenvcha.2009.08.004.

Page, E. A. (2007). Intergenerational justice of what: Welfare, resources or capabilities? Environmental Politics, 16(3), 453-469. https://doi.org/10.1080/09644010701251698.

Potthast, T. (2015). Ethics in the sciences beyond Hume, Moore and Weber: Taking epistemic-moral hybrids seriously. In S. Meisch, J. Lundershausen, L. Bossert, \& M. Rockoff (Eds.), Ethics of science in the research for sustainable development (pp. 129-152). Baden-Baden: Nomos.

Robeyns, I. (2019). What if anything is wrong with extreme wealth? Journal of Human Development and Capabilities, 20(3), 251-266.

Ricken, F. (2013). Allgemeine Ethik (5. revised and expanded ed.). Stuttgart: Kohlhammer.

Salisu Barau, A., \& Stringer, L. C. (2015). Access to and allocation of ecosystem services in Malaysia's Pulau Kukup Ramsar Site. Ecosystem Services, 16, 167-173. https://doi.org/10.1016/j.ecose r.2015.10.021.

Sandel, M. (2010). Justice: What's the right thing to do?. New York: Farrar, Straus and Giroux.

Schlosberg, D. (2013). Theorising environmental justice: The expanding sphere of a discourse. Environmental Politics, 22(1), 37-55. https://doi.org/10.1080/09644016.2013.755387.

Schlosberg, D., \& Coles, R. (2015). The new environmentalism of everyday life: Sustainability, material flows, and movements. Contemporary Political Theory, 15, 160-181.

Schroeder, H. (2014). Governing access and allocation in the Anthropocene. Global Environmental Change, 26, A1-A3. https://doi.org/10.1016/j.gloenvcha.2014.04.017.

Schroeder, H., \& McDermott, C. (2014). Beyond carbon: enabling justice and equity in REDD+ across levels of governance. Ecology and Society, 19(1), 31. https://doi.org/10.5751/ES-06537-190131.

Sikor, T., \& Newell, P. (2014). Globalizing environmental justice? Geoforum, 54, 151-157. https://doi. org/10.1016/j.geoforum.2014.04.009.

Spengler, L. (2016). Two types of 'enough': Sufficiency as minimum and maximum. Environmental Politics, 25(5), 921-940. https://doi.org/10.1080/09644016.2016.1164355.

Stadelmann, M., Persson, Å., Ratajczak-Juszko, I., \& Michaelowa, A. (2014). Equity and cost-effectiveness of multilateral adaptation finance: Are they friends or foes? International Environmental Agreements: Politics, Law and Economics, 14(2), 101-120. https://doi.org/10.1007/s10784-013-9206-5.

Tugendhat, E. (1993). Vorlesungen über Ethik. Frankfurt/Main: Suhrkamp.

Zeitoun, M., Lankford, B., Krueger, T., Forsyth, T., Carter, R., Hoekstra, A. Y., et al. (2016). Reductionist and integrative research approaches to complex water security policy challenges. Global Environmental Change, 39, 143-154. https://doi.org/10.1016/j.gloenvcha.2016.04.010.

\section{Bibliography Annex}

Bastos Lima, M. G., \& Gupta, J. (2013). The policy context of biofuels: A case of non-governance at the global level? Global Environmental Politics, 13(2), 46-64. https://doi.org/10.1162/GLEP_a_00166.

Biermann, F. (2007). 'Earth system governance' as a crosscutting theme of global change research. Global Environmental Change, 17(3), 326-337. https://doi.org/10.1016/j.gloenvcha.2006.11.010.

Biermann, F. (2014). Earth System Governance: World politics in the Anthropocene. Cambridge, MA: MIT.

Biermann, F., Abbott, K., Andresen, S., Bäckstrand, K., Bernstein, S., Betsill, M. M., et al. (2012a). Navigating the Anthropocene: Improving Earth System Governance. Science, 335(6074), 1306. https://doi. org/10.1126/science.1217255.

Biermann, F., Abbott, K., Andresen, S., Bäckstrand, K., Bernstein, S., Betsill, M. M., et al. (2012b). Transforming governance and institutions for global sustainability: Key insights from the Earth System Governance Project. Current Opinion in Environmental Sustainability, 4(1), 51-60. https://doi. org/10.1016/j.cosust.2012.01.014.

Biermann, F., Betsill, M. M., Gupta, J., Kanie, N., Lebel, L., Liverman, D., et al. (2010). Earth system governance: A research framework. International Environmental Agreements: Politics, Law and Economics, 10(4), 277-298. https://doi.org/10.1007/s10784-010-9137-3.

Biermann, F., \& Zondervan, R. (2009). Managing global change: Earth system governance. Retrieved May 13, 2019, from http://www.thebrokeronline.eu/Articles/Managing-global-change.

Cerbu, G. A., Swallow, B. M., \& Thompson, D. Y. (2011). Locating REDD: A global survey and analysis of REDD readiness and demonstration activities. Environmental Science \& Policy, 14(2), 168-180. https ://doi.org/10.1016/j.envsci.2010.09.007. 
Coolsaet, B. (2015). Conclusion Comparing access and benefit-sharing in Europe. In B. Coolsaet, F. Batur, A. Broggiato, J. Pitseys, \& T. Dedeurwaerdere (Eds.), Implementing the Nagoya Protocol (pp. 363386). Leiden: BrilliNijhoff.

Coolsaet, B., Batur, F., Broggiato, A., Pitseys, J., \& Dedeurwaerdere, T. (2015). Implementing the Nagoya Protocol. Leiden: BrilliNijhoff.

Coolsaet, B., \& Pitseys, J. (2015). Fair and equitable negotiations? African influence and the international access and benefit-sharing regime. Global Environmental Politics, 15(2), 38-56. https://doi. org/10.1162/GLEP_a_00297.

Corbera, E., Kosoy, N., \& Martínez Tuna, M. (2007). Equity implications of marketing ecosystem services in protected areas and rural communities: Case studies from Meso-America. Global Environmental Change, 17(3), 365-380. https://doi.org/10.1016/j.gloenvcha.2006.12.005.

Corbera, E., \& Schroeder, H. (2011). Governing and implementing REDD+. Environmental Science \& Policy, 14(2), 89-99. https://doi.org/10.1016/j.envsci.2010.11.002.

Falaleeva, M., O’Mahony, C., Gray, S., Desmond, M., Gault, J., \& Cummins, V. (2011). Towards climate adaptation and coastal governance in Ireland: Integrated architecture for effective management? Marine Policy, 35(6), 784-793. https://doi.org/10.1016/j.marpol.2011.01.005.

Gero, A., Méheux, K., \& Dominey-Howes, D. (2010). Disaster risk reduction and climate change adaptation in the Pacific: The challenge of integration. Sydney: Australian Tsunami Research CentreNatural Hazards Research Laboratory, University of New South Wales.

Gupta, J. (2018). Sharing our water. In J. Vos, R. Boelens, \& T. Perreault (Eds.), Water justice (pp. 259-274). Cambridge: Cambridge University Press.

Gupta, J., \& Lebel, L. (2010). Access and allocation in earth system governance: Water and climate change compared. International Environmental Agreements: Politics, Law and Economics, 10(4), 377-395. https://doi.org/10.1007/s10784-010-9139-1.

Gupta, J., \& Pahl-Wostl, C. (2013). Global water governance in the context of global and multilevel governance: Its need, form, and challenges. Ecology and Society. https://doi.org/10.5751/es-05952 -180453 .

Habtezion, S., Adelekan, I., Aiyede, E., Biermann, F., Fubara, M., Gordon, C., et al. (2015). Earth System Governance in Africa: Knowledge and capacity needs. Current Opinion in Environmental Sustainability, 14, 198-205. https://doi.org/10.1016/j.cosust.2015.06.009.

Inoue, C. Y. A., \& Moreira, P. F. (2016). Many worlds, many natures, one planet: Indigenous knowledge in the Anthropocene. Revista Brasiliera de Política Internacional, 59(2), e009. https://doi. org/10.1590/0034-7329201600209.

Inoue, C. Y. A., \& Tickner, A. B. (2016). Many worlds, many theories? Revista Brasiliera de Política Internacional, 59(2), e001. https://doi.org/10.1590/0034-7329201600201.

Kalfagianni, A. (2014). Addressing the global sustainability challenge: The potential and pitfalls of private governance from the perspective of human capabilities. Journal of Business Ethics, 122(2), 307-320. https://doi.org/10.1007/s10551-013-1747-6.

Kanie, N., Nishimoto, H., Hijioka, Y., \& Kameyama, Y. (2010). Allocation and architecture in climate governance beyond Kyoto: Lessons from interdisciplinary research on target setting. International Environmental Agreements: Politics, Law and Economics, 10(4), 299-315. https://doi.org/10.1007/ s10784-010-9143-5.

Kanie, N., Zondervan, R., \& Stevens, C. (2014). Ideas on Governance 'of' and 'for' sustainable development goals: UNU-IAS/POST2015 conference report. Tokyo: United Nations University Institute for the Advanced Study of Sustainability, Tokyo Institute of Technology, Earth System Governance Project.

Klinsky, S., \& Dwlatabadi, H. (2009). Conceptualizations of justice in climate policy. Climate Policy, 9(1), 88-108. https://doi.org/10.3763/cpol.2008.0583b.

Klinsky, S., Roberts, T., Huq, S., Okereke, C., Newell, P., Dauvergne, P., et al. (2017). Why equity is fundamental in climate change policy research. Global Environmental Change, 44, 170-173. https ://doi.org/10.1016/j.gloenvcha.2016.08.002.

Kohler, F. T. G., Holland, J. S., Kotiaho, M. Desrousseaux, \& Potts, M. D. (2019). Embracing diverse worldviews to share planet Earth. Conservation Biology, 33(5), 1014-1022. https://doi.org/10.1111/ cobi.13304.

LenkaBula, P. (2008). Beyond anthropocentricity-Botho/Ubuntu and the quest for economic and ecological justice in Africa. Religion and Theology, 15, 375-394.

Martin, A., Coolsaet, B., Corbera, E., Dawson, N. M., Fraser, J. A., Lehmann, I., et al. (2016). Justice and conservation: The need to incorporate recognition. Biological Conservation, 197, 254-261. https://doi.org/10.1016/j.biocon.2016.03.021. 
Mattor, K., Betsill, M., Huayhuaca, C. A., Huber-Stearns, H., Jedd, T., Sternlieb, F., et al. (2014). Transdisciplinary research on environmental governance: A view from the inside. Environmental Science \& Policy, 42, 90-100. https://doi.org/10.1016/j.envsci.2014.06.002.

Meisch, S. (2016). A fair distribution in the Anthropocene: A normative conception of sustainable development. In P. Pattberg \& F. Zelli (Eds.), Environmental politics and governance in the Anthropocene. Institutions and legitimacy in a complex world (pp. 62-78). London: Routledge.

Michael, K., \& Vakulabharanam, V. (2016). Class and climate change in post-reform India. Climate and Development, 8(3), 224-233. https://doi.org/10.1080/17565529.2015.1034235.

Morin, J.-F., Trudeau, H., Duplessis, I., Lalonde, S., Van de Graaf, T., De Ville, F., et al. (2013). Insights from Global Environmental Governance. International Studies Review, 15(4), 562-589. https://doi. org/10.1111/misr.12070.

Okereke, C. (2008). Equity norms in Global Environmental Governance. Global Environmental Politics, 8(3), 25-50. https://doi.org/10.1162/glep.2008.8.3.25.

Okereke, C., \& Dooley, K. (2010). Principles of justice in proposals and policy approaches to avoided deforestation: Towards a post-Kyoto climate agreement. Global Environmental Change, 20(1), 82-95. https ://doi.org/10.1016/j.gloenvcha.2009.08.004.

Parsons, M., Nalau, J., \& Fisher, K. (2017). Alternative perspectives on sustainability: Indigenous knowledge and methodologies. Challenges in Sustainability, 5(1), 7-14.

Rabitz, F. (2017). The global governance of genetic resources: Institutional change and structural constraints. London: Routledge.

Salisu Barau, A., \& Stringer, L. C. (2015). Access to and allocation of ecosystem services in Malaysia's Pulau Kukup Ramsar Site. Ecosystem Services, 16, 167-173. https://doi.org/10.1016/j.ecose r.2015.10.021.

Schroeder, H. (2014). Governing access and allocation in the Anthropocene. Global Environmental Change, 26, A1-A3. https://doi.org/10.1016/j.gloenvcha.2014.04.017.

Schroeder, H., Boykoff, M. T., \& Spiers, L. (2012). Equity and state representations in climate negotiations. Nature Climate Change, 2, 834. https://doi.org/10.1038/nclimate1742.

Stadelmann, M., Persson, A., Ratajczak-Juszko, I., \& Michaelowa, A. (2014). Equity and cost-effectiveness of multilateral adaptation finance: Are they friends or foes? International Environmental Agreements: Politics, Law and Economics, 14(2), 101-120. https://doi.org/10.1007/s10784-013-9206-5.

Vanhulst, J., \& Beling, A. E. (2014). Buen vivir: Emergent discourses within or beyond sustainable development? Ecological Economics, 101, 54-63. https://doi.org/10.1016/j.ecolecon.2014.02.017.

Zeitoun, M., Lankford, B., Krueger, T., Forsyth, T., Carter, R., Hoekstra, A. Y., et al. (2016). Reductionist and integrative research approaches to complex water security policy challenges. Global Environmental Change, 39, 143-154. https://doi.org/10.1016/j.gloenvcha.2016.04.010.

Publisher's Note Springer Nature remains neutral with regard to jurisdictional claims in published maps and institutional affiliations. 